\title{
Hurricane disturbances, tree diversity, and succession in North Carolina Piedmont forests, USA
}

\author{
Weimin $\mathrm{Xi}^{1,2} \cdot$ Robert K. Peet $^{1} \cdot$ Michael T. Lee ${ }^{1} \cdot$ Dean L. Urban $^{3}$
}

Received: 18 July 2018/Accepted: 29 August 2018/Published online: 1 October 2018

(C) The Author(s) 2018

\begin{abstract}
Windthrow plays a critical role in maintaining species diversity in temperate forests. Do large-scale strong wind events (i.e., tropical cyclones, including hurricanes, typhoons and severe cyclonic storms) increase tree diversity in severely damaged forest areas? Do hurricanes (tropical cyclones that occurs in the Atlantic Ocean and northeastern Pacific Ocean) lead to altered relative abundance of shade-tolerant and shade-intolerant species? Did historic hurricanes alter the succession trajectory of the damaged forests? We used nearly 70-year tree demographic data to assess the effects of two major hurricanes on woody species diversity in Piedmont forests, North Carolina, USA. Species richness $(S)$ and Shannon-Wiener's diversity index $\left(H^{\prime}\right)$ were used to evaluate the changes in tree diversity. The changes in composition were assessed with Nonmetric Multidimensional Scaling. The pre-hurricane successional phase can strongly influence both the damage severity and subsequent responses. Although there is often an immediate drop in diversity following a
\end{abstract}

Project funding: This work was supported by a grant from the National Science Foundation (DEB-97-07551).

The online version is available at http://www.springerlink.com

Corresponding editor: Yu Lei.

Weimin Xi

weimin.xi@tamuk.edu

1 Department of Biology, University of North Carolina at Chapel Hill, Chapel Hill, NC 27599-3280, USA

2 Department of Biological and Health Sciences, Texas A \& M University-Kingsville, Kingsville, TX 78363-8202, USA

3 The Nicholas School of the Environment, Duke University, Durham, NC 27708, USA hurricane, understory tree diversity quickly increases to levels that exceed those prior to the disturbance. This leads to an increase in diversity in stands that were substantially damaged. Hurricanes significantly decrease the dominance of shade-intolerant canopy species while increasing preestablished, more shade-tolerant species. We conclude that large, and infrequent hurricanes help to maintain local tree diversity, but also accelerate the increase in dominance of understory species such as red maple and beech.

Keywords Wind disturbance - Tree species diversity . Plant succession - Disturbance-diversity relationship . Piedmont forests

\section{Introduction}

Windthrows caused by large hurricanes and other intensive windstorms have profound impacts on forest structure (Imbert et al. 1998; Greenberg and McNab 1998; Elliott et al. 2002; Xi et al. 2008a; Yang et al. 2017), species composition (Spurr 1956; Putz and Sharitz 1991; Vandermeer et al. 2000; Xi et al. 2008b; Li et al. 2018), successional development (Hibbs 1983), carbon storage and emissions (Owari et al. 2011), and have been hypothesized to play a critical role in maintaining species diversity in temperate forests (Peet and Christensen 1980; Beckage et al. 2000; Xi et al. 2008a (also see reviews in Everham and Brokaw 1996; Webb 1999; Peterson 2000; Zhu et al. 2004; Xi and Peet 2011; Xi 2015). What is less clear is: (1) how the pre-disturbance community or successional stage influences species diversity; (2) how the juxtaposition of background dynamics and succession influences the postdisturbance trajectory of species diversity; and, (3) how long the disturbance effects influence species replacement 
and successional trajectory. Clarifying these issues is important for understanding forest recovery, species dynamics, and disturbance-diversity relationships.

Intensive windstorms generally result in immediate changes in forest structure and altered rates of population processes (e.g., morality, growth rates and biomass change), but their impacts on community attributes such as species diversity and long-term forest succession are more complex (Xi and Peet 2011; Xi 2015). Windstorms may have positive or negative effects on forest diversity and succession depending on their intensity and frequency and the characteristics of the pre-disturbance communities (White and Jentsch 2004; Xi et al. 2008b; Xi 2015). Species diversity at any time is the result of a dynamic balance of recruitment and extirpation of species that reflects the combined influence of historical disturbance and population change. Thus, to better understand disturbance-mediated species dynamics, it is important to analyze disturbance effects in the context of successional change. Clearly, many years of pre- and post-disturbance data are critical for understanding long-term tree diversity dynamics.

Demographic research in the Duke Forest (North Carolina, USA) has shown long-term oak and hickory canopy dominance steadily declining over the past 60 years, along with a simultaneous increase in abundance of Acer rubrum L. (red maple), and to a lesser extent, Fagus grandifolia Ehrh. (American beech) (McDonald et al. 2002). The mechanisms for this compositional shift are little understood. One popular hypothesis among several is that oaks and hickories are well- adapted to the chronic, low-intensity fires that ceased during the late 1800s (Abrams 1992). Another hypothesis receiving consistent support is that these relatively shade-intolerant species are adapted to rapid growth following major canopy disturbances (Glitzenstein et al. 1986). A detailed analysis of post-hurricane recovery trajectories could provide insights that discriminate between these possibilities.

We use nearly 70-year tree demographic data to assess the effect of two major hurricanes, Hurricane Hazel in 1954 and Fran in 1996, on species diversity, tree replacement, and long-term successional trajectories in Piedmont forests. We focus on hurricane-disturbance mediated tree diversity dynamics. The effects of Hurricane Hazel on tree diversity were examined by comparing the changes in hurricane-damaged plots with changes in plots which received little to no damage. To clarify long-term effects of hurricanes on the relative abundance of tree diversity, we compare post-Fran recovery patterns with those following Hurricane Hazel and conclude by examining how the historical hurricanes influence long-term forest dynamics. Finally, we compare major tree replacement rates among communities in different successional stages before and after hurricanes to understand how large, infrequent hurricanes can alter forest successional trajectories.

The long-term, pre- and post-hurricane data in the Duke Forest allow us to compare population dynamics and recovery patterns in two forest types (even-aged pine stands and mixed-aged hardwood forests) and across three successional stages (the thinning phase, the transition phase and the steady-state phase) to address three questions: (1) Do hurricanes increase tree diversity in severely damaged plots? (2) Do hurricanes lead to altered relative abundance of shade-tolerant and shade-intolerant species? (3) Did hurricanes Hazel and Fran alter the succession trajectory of Piedmont forests they impacted?

\section{Materials and methods}

\section{The study site}

The study was conducted in the Duke Forest, located in Orange and Durham Counties, North Carolina, USA (approximately $35^{\circ} 52^{\prime} \mathrm{N}, 79^{\circ} 59^{\prime} \mathrm{W}$ ). This experimental forest has served as a model system for old-field succession since its establishment in the early 1930s (Oosting 1942; Bormann 1953; Christensen 1977; Christensen and Peet 1981, 1984; Peet and Christensen 1980, 1987, 1988; see reviews by Peet 1992; Xi and Peet 2008a, b). As part of this legacy of prior research, there exists a set of long-term data on tree establishment, growth, and mortality of individuals in permanently marked research plots. These data, in some cases over 70 years old, include pre- and post-hurricane records for 1954 Hazel and 1996 Fran.

The major forest types of the Duke Forest are even-aged loblolly pines and uneven-aged mixed upland hardwood forest (Peet and Christensen 1980, 1987, 1988; Xi 2005; Xi et al. 2008b). Most of the current loblolly pine stands are 90- to 110-year-old secondary forests that are the result of reversion of abandoned farmland $(\mathrm{Xi} 2005$; $\mathrm{Xi}$ et al. $2008 \mathrm{a}, \mathrm{b})$. These forests, in the transition phase of succession, have a pine canopy and an understory of hardwood trees and shrubs more tolerant of low resource availability (Peet 1992). The uneven-aged, mixed upland hardwoods are the putative 'climax' forest of the Piedmont region and are in the steady-state terminal phase of succession (Oosting 1942; Christensen 1977; Christensen and Peet 1981; Xi 2005; Xi et al. 2008b). The younger hardwoods are dominated by species such as Liquidambar styraciflua L. (sweetgum), Liriodendron tulipifera L. (tuliptree), Acer rubrum (red maple) and Ostrya virginiana (Mill.) K. Koch (American hophornbeam). The classical expectation is that the composition of the younger hardwood forest will probably change gradually for another 200-500 years as these species are replaced by the slow growing Quercus 
rubra L. (red oak), Q. alba L. (white oak), Carya glabra Miller (pignut hickory), C. ovata (Mill.) K. Koch (shagbark hickory) and Fraxinus spp. (ash) (Oosting 1942; Bormann 1953; Peet and Christensen 1980, 1987, 1988; Xi 2005; Palmer et al. 2007; Xi et al. 2008a).

\section{Disturbance history}

Prior to European colonization (ca. 1650-1750), Native American tribes used fire to manage woodlands. After European colonization, a large portion of the Piedmont forest was converted into cropland. During the latter half of the 1800s and early 1900s, much of the farmland was abandoned, and what remained has largely progressed through old-field succession (Oosting 1942). Much of the Piedmont forest land today is in some stage of recovery from this abandonment (Peet and Christensen 1980).

Wildfires have been suppressed in the Duke Forest since the 1930s. Some stands have received moderate management, although there were no clear-cuts. The forest experienced various natural disturbances, including hurricanes, ice storms, and local severe windstorms. Hurricanes are the most destructive force of nature occurring in this ecosystem and occur on average about once every 50 years (Xi 2005; Xi et al. 2008a, b). Over the past 100 years, two major hurricanes (Hazel in 1954 and Fran in 1996) have substantially damaged the Duke Forest woodlands and caused widespread wind throws.

Hurricane Hazel was recognized as the greatest natural disaster to affect central North Carolina (Barnes 2001). It made landfall as a category-4 hurricane on October 15, 1954. Heavy rains of up to $280 \mathrm{~mm}$ occurred far inland and resulted in local flooding. At the Raleigh-Durham Airport, the nearest official weather station to the Duke Forest, wind gusts of $40.23 \mathrm{~m} \mathrm{~s}^{-1}$ were recorded (the State Climate Office of North Carolina and the National Hurricane Center), and caused widespread tree mortality and breakage.

Hurricane Fran was one of the most destructive hurricanes in the North Carolina Piedmont region and the fourth most costly hurricane on the United States mainland during the 20th century. Fran was a category-3 hurricane and struck Duke Forest on September 6, 1996 (Barnes 2001). Although its intensity had begun to decrease to tropical storm levels, Fran caused significant tree damage in and near Duke Forest. The maximum sustained wind speeds at the Raleigh-Durham airport were $26.82 \mathrm{~m} \mathrm{~s}^{-1}$ and the maximum wind gusts reached $31.85 \mathrm{~m} \mathrm{~s}^{-1}$. Fran brought $224 \mathrm{~mm}$ of rainfall to the region. In the 2 days prior to Fran, Duke Forest received nearly $76 \mathrm{~mm}$ of rainfall. The resulting saturation of soils was particularly significant as it reduced the ability of canopy trees to withstand high winds (the State Climate Office of North Carolina and the National Hurricane Center).

\section{Vegetation plots and data}

We used two sets of long-term demographic data to examine the effects of historical hurricanes on the change of species diversity during secondary succession. The first dataset of 20 permanent sample plots (PSPs) contain nearly 70 years (ca. 1933-2000) of data on all woody stems greater than $1.25 \mathrm{~cm}$ diameter at breast height $(\mathrm{DBH}$ at $1.37 \mathrm{~m}$ height), including $\mathrm{DBH}$, height, and condition (alive or dead). The size of the 20 selected PSPs ranged from 404 to $1440 \mathrm{~m}^{2}$. The selected PSPs were established to study the effects of thinning treatments on tree growth and timber yield. A set of the plots received thinning treatment and were paired with plots in control stands. To examine the effects of Hazel and Fran on tree diversity and succession, we further divided these 20 PSPs into three groups:

(1) The first group consists of 14 control PSPs that were not subjected to thinning treatments and experienced no major hurricane damage during Hazel (Table 1). Three plots experienced minor tree damage (hurricane-induced plot-level basal area loss of less than 10\%). Ten loblolly pine PSPs were about 10-20 year-old in the early 1930s when the plots were established. Four mixed-aged hardwood PSPs were relatively open hardwood stands when the plots were established. These stands increased in biomass and canopy tree size over the next 60 years until Fran, and did not experience any other form of major damage. During Fran, five PSPs in this group (PSP 10, 14, 19, 50, and 36) experienced a high degree of tree damage and morality (with basal area loss $\geq 10 \%$ of previous basal area).

(2) The second group contains plots with significant damage in 1954 from Hazel (basal area loss $\geq 10 \%$ of previous basal area) (Table 2). This group includes two control PSPs without original thinning treatment. One is a loblolly pine plot (PSP 40) with 14\% basal area loss, and other a hardwood plot (PSP 37) with over $42 \%$ basal area loss after Hazel.

(3) The third group experienced significant hurricane damage during Hazel and was subjected to thinning treatments from early 1930-1960s. Three PSPs were in pine stands, and one was in a hardwood stand. PSP 20 and PSP 22 lost 16.19 and 20.23 trees/ha and $12 \%$ and $8 \%$ of the previous basal area, respectively. PSP 39 received a heavy thinning treatment from below (removal of about $47 \%$ of the previous basal area) in 1934, and had extensive Hazel damage 20 years later (loss of 36.42 trees/ha and about $36 \%$ previous basal area). In addition, this plot was also extensively damaged in a glaze storm in 1947. PSP 43 is a hardwood plot that experienced thinning at the time of 
Table 1 Changes in the Shannon-Wiener's index of diversity $\left(e^{H^{\prime}}\right)$ of trees $>1.25 \mathrm{~cm} \mathrm{DBH}$ in 14 selected permanent sampling controls (Group 1) in the Duke Forest

\begin{tabular}{rrrrrrrrrrrr}
\hline Plot no. & Size $\left(\mathrm{m}^{2}\right)$ & Initial age & 1933 & 1953 & 1963 & 1973 & 1984 & 1988 & 1992 & 1997 & 2000 \\
\hline Group 1: Loblolly pine stands & & & & & & & & & \\
PSP 12 & 404 & 8 & 1.00 & $-*$ & $-*$ & $-*$ & 8.54 & 7.92 & 7.95 & 7.46 & 7.99 \\
PSP 14 & 404 & 8 & 1.00 & - & - & - & 6.62 & 7.79 & 8.39 & 9.07 & 11.11 \\
PSP 15 & 404 & 8 & 1.00 & - & - & - & 10.00 & 10.73 & 11.01 & 11.32 & 11.19 \\
PSP 17 & 404 & 8 & 1.10 & - & - & - & 2.98 & 4.54 & 6.12 & 9.53 & 11.12 \\
PSP 19 & 404 & 8 & 1.27 & - & - & - & 7.18 & 8.55 & 9.99 & 11.26 & 10.27 \\
PSP 21 & 404 & 8 & 1.05 & - & - & - & 4.84 & 5.18 & 6.03 & 7.97 & 10.04 \\
PSP 23 & 404 & 8 & 1.02 & - & - & - & 5.79 & 7.30 & 8.16 & 8.22 & 7.84 \\
PSP 26 & 1012 & 19 & 3.78 & - & - & - & 7.21 & 6.76 & 6.74 & 6.70 & 6.75 \\
PSP 28 & 808 & 15 & 1.18 & - & - & - & 7.24 & 7.11 & 6.97 & 6.49 & 6.39 \\
PSP 50 & 900 & 25 & 6.23 & - & - & - & 9.65 & 9.70 & 11.53 & 12.31 & 13.52 \\
Group1: Upland hardwoods & & & & & & & & & \\
PSP 10 & 1025 & Mixed & 4.83 & - & - & - & 9.56 & 10.28 & 11.09 & 11.59 & 10.58 \\
PSP 35 & 1012 & Mixed & 4.08 & - & - & - & 9.04 & 7.56 & 7.21 & 7.15 & 7.33 \\
PSP 36 & 1365 & Mixed & 6.08 & - & - & - & 7.28 & 6.96 & 6.97 & 6.31 & 5.93 \\
PSP 44 & 1118 & Mixed & 9.70 & - & - & - & 15.46 & 13.37 & 12.86 & 12.43 & 13.41 \\
\hline
\end{tabular}

*Omitted due to changed survey protocol. All size of trees were recorded in the initial survey in 1933; however, only trees $>2.5 \mathrm{~cm}$ DBH were recorded in the surveys in 1953, 1963 and 1973. After 1973, all trees $>1.25 \mathrm{~cm} \mathrm{DBH}$ were recorded. Therefore, the Shannon-Wiener's index of diversity $\left(e^{H^{\prime}}\right)$ in the years 1953, 1963 and 1973 were omitted in this table

\begin{tabular}{|c|c|c|c|c|c|c|c|c|c|c|c|}
\hline Plot no. & Size $\left(\mathrm{m}^{2}\right)$ & Initial age & 1933 & 1953 & 1963 & 1973 & 1984 & 1988 & 1992 & 1997 & 2000 \\
\hline \multicolumn{12}{|c|}{ Group 2: Control pine plot with Hazel damage } \\
\hline PSP 40 & 808 & 15 & 1.58 & $-*$ & $-*$ & $-*$ & 9.70 & 9.27 & 8.67 & 8.76 & 9.43 \\
\hline \multicolumn{12}{|c|}{ Group 2: Control hardwood plot with Hazel damage } \\
\hline PSP 37 & 1440 & Mixed & 5.33 & - & - & - & 10.51 & 9.62 & 9.18 & 8.66 & 9.14 \\
\hline \multicolumn{12}{|c|}{ Group 3: Thinning pine stands with Hazel damage } \\
\hline PSP 20 & 400 & 8 & 1.00 & - & - & - & 3.72 & 3.91 & 4.92 & 5.66 & 6.09 \\
\hline PSP 22 & 400 & 8 & 1.05 & - & - & - & 6.37 & 6.17 & 6.91 & 8.08 & 9.20 \\
\hline PSP 39 & 808 & 15 & 1.12 & - & - & - & 7.29 & 7.18 & 7.56 & 7.52 & 8.00 \\
\hline \multicolumn{12}{|c|}{ Group 3: Thinning hardwood plus with Hazel damage } \\
\hline PSP 43 & 1102 & Mixed & 8.97 & - & - & - & 9.23 & 9.58 & 9.33 & 10.31 & 9.30 \\
\hline
\end{tabular}

These plots were significantly damaged by Hurricane Hazel in 1954, and two were controls without original thinning (Group 2), and four had a thinning prior to Hazel (Group 3)

*Omitted due to changed survey protocol. All size trees were recorded in the initial survey in 1933; however, only trees $>2.5 \mathrm{~cm}$ DBH were recorded in the surveys in 1953, 1963 and 1973. After 1973, all trees $>1.25 \mathrm{~cm}$ DBH were recorded. Therefore, the Shannon-Wiener's index of diversity $\left(e^{H^{\prime}}\right)$ in years of 1953, 1963 and 1973 were omitted in this table establishment and in addition lost $33 \%$ of the previous basal area during 1954 Hurricane Hazel.

The second dataset consists of seven large (0.68-6.5 ha) mapped permanent plots (MAPs) from the Duke Forest with over 20 years, of tree data $(\mathrm{DBH}>1 \mathrm{~cm})$ to study spatial patterns and process (Peet and Christensen 1980; Xi et al. 2008a, b). The seven mapped plots include the same data as the PSPs except that tree height was not recorded. Mapped plots were sampled at roughly 5-year intervals from 1978 to 2000. We focused primarily on two large mapped plots. MAP 1 was dominated by even-aged loblolly pine and was sampled from 1978 to 2001. MAP 2 was a mixed-aged hardwood stand with tree records from 1950 to 2000. These two MAPs were chosen to represent two major types of forest at two different succession phases: the transition phase and the steady-state phase. Both mapped plots experienced significant tree damage and mortality in the 1996 Hurricane Fran (Xi 2005; Xi et al. 2008a, b). 


\section{Measurement of species diversity and data analysis}

We used two indices, species richness $(S)$ and ShannonWiener's diversity index $\left(H^{\prime}\right)$, to evaluate the change in woody plant diversity as a consequence of hurricane damage. Since methodologies and plot sizes were dissimilar for the different plots, we used slightly modified definitions for each type of plot. We define species richness $(S)$ as the number of vascular tree species with at least one stem of DBH $\geq 1.25 \mathrm{~cm}$ per 0.04 ha plot when comparing pine PSPs and per 0.1 ha for hardwood PSPs, but DBH $\geq 1 \mathrm{~cm}$ per 0.1 ha when comparing between the MAPs. We divided each large mapped plot into continuous, square subplots ( 0.1 ha in size) to examine changes in tree diversity. The plot size of 0.1 ha is widely used as a standard sampling size in temperate forests, which facilitates comparison with other Piedmont forest plots (Peet et al. 1998). In this way, we minimized the possible sample effects that would arise from using unequal plot sizes.

The Shannon-Wiener diversity index $\left(H^{\prime}\right)$ is widely used in ecology and is defined as:

$H^{\prime}=-\sum p_{i} \ln p_{i}$

where, $p_{i}$ is the proportion of individuals in the $i$ th species. We expressed this form of diversity as $e^{H^{\prime}}$ which gives a value equal to the number of equally common species that would provide the same value of $H^{\prime}$ as the sample. Thus, $e^{H^{\prime}}$ is a more intuitively meaningful expression than $H^{\prime}$ (Peet 1974).

Compositional patterns were assessed with Nonmetric Multidimensional Scaling (NMS) with varimax rotation as implemented in version 4.39 of PC-ORD (McCune and Grace 2002). Ordinations of multiple plot measurements over time allowed for the examination of plot successional trajectories in ordination space and patterns of community change. All control PSPs (1933-2000) were used to assess the range of change of tree species composition. We analyzed data from the seven MAPs (1978-2000) to explain changes in compositional patterns within upland stands impacted by Hurricane Fran.

\section{Results}

\section{Tree diversity dynamics in old-field succession without major disturbances}

We examined PSP data from 66-year records to document diversity trends in tree species for both even-aged loblolly pine stands from the thinning phase through to the transition phase, and relatively mature upland mixed-aged hardwood stands (Table 1).
As shown in the 10 loblolly pine control stands, tree richness and diversity in 10-25 year-old loblolly pine stands was generally low in 1933 when the plots were first established. During this thinning phase, these stands were mainly comprised of loblolly pine plus a few shade-intolerant hardwoods such as Liquidambar styraciflua (sweetgum) and Liriodendron tulipifera (tuliptree). Most of the 10 controls had only $1-3$ tree species with an average value of $e^{H^{\prime}}$ of 1.86. Tree richness and diversity increased by about a factor of $5\left(e^{H^{\prime}} 7.01\right)$ when these loblolly pine stands reached 60-75 years-old and entered the transition phase in 1984. Tree diversity continued to increase at a lower rate to 8.29 in 1992 , the last overall census prior to Hurricane Fran (Table 1). Although there was considerable variation among these pine stands due to differences in site conditions and stand ages, the overall trend of increasing tree species diversity in pine stands during the 60 years of succession was clear and significant.

There was substantial variation in tree species richness among the pine stands at 10-25 years in age (Table 1). PSP 26 and PSP 50 in ca. 20-year-old stands had high tree species richness, perhaps due to richer soils. This suggests that rapid post-abandonment tree species recruitment sometimes occurs during the early thinning phase.

In contrast to the loblolly pine stands, tree species diversity and richness in the four undisturbed upland mixed-aged hardwood plots showed an initial increase and then remained relatively stable for most of the 60-year period of record (Table 1). However, the observed tree species diversity was lower than in the transition-phase 90 -year-old pine stands.

\section{Changes in mortality and density in old-field succession}

Tree mortality is the dominant population process driving secondary old-field succession (Peet and Christensen 1980). Long-term changes in tree mortality and density were examined in this study, and we found that there has been a relatively constant rate of tree morality during pine stand development, even though initial tree density varied greatly. In each of the comparable plots, after critical crowding was reached, mortality showed a nearly perfect exponential decrease (Peet and Christensen 1980). The stem density of pines steadily decreased and converged to a rather narrow range of densities during nearly 70 years of thinning. Tree density strongly influences mortality and species diversity along the succession process (Fig. 1).

Tree mortality in the mixed-aged hardwood stands is less easily interpreted during the nearly 70 years of stand records, primary due to the ever-changing age structure of the populations and size dependence of mortality (Peet and Christensen 1988). Cornus florida L. (flowering dogwood) 


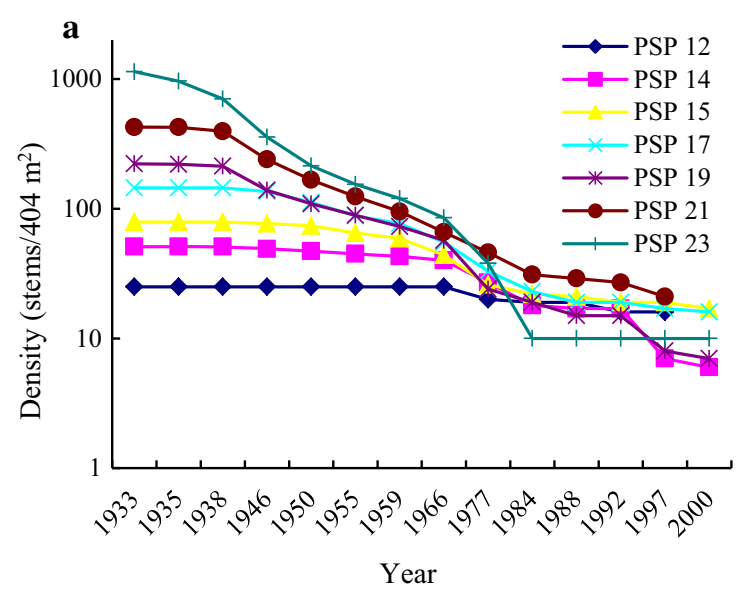

Fig. 1 Survival of Pinus taeda $(\mathrm{DBH}>1.25 \mathrm{~cm})$ in 11 even-aged loblolly pine stands of various initial densities over a 66-year period. The plot sizes are $404 \mathrm{~m}^{2}$ for (a) group and $808-1011 \mathrm{~m}^{2}$ for (b) group. Despite extreme variation in initial densities, different

has the highest depletion rates of any of the common species (Fig. 2). This is consistent with a high mortality trend that has been observed throughout the species range due to several factors, including anthracnose infection (Jenkins and White 2002). We infer that a significant portion of Cornus mortality is due to anthracnose infection although a lack of data prevents us from distinguishing the causes of mortality.

\section{Damage effects of Hurricane Hazel on tree diversity in the thinning phase stands}

Comparison of change in diversity in PSPs severely damaged by Hurricane Hazel with their controls during the

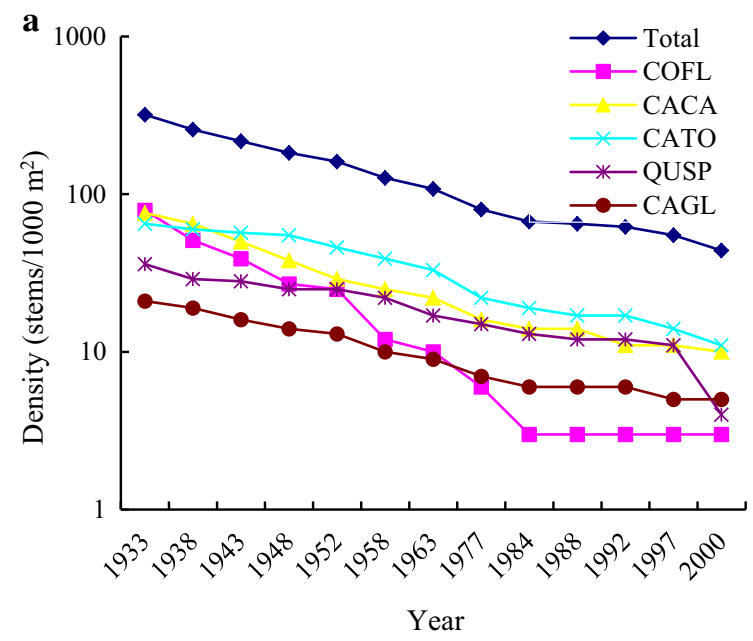

Fig. 2 Depletion curves illustrating differences in mortality rates of trees from two upland, mixed-aged, mixed-species stands. Species abbreviations: CARY-Carya spp; CACA-Carya carolinae-septentrionalis; CATO-Carya tomentosa; CAGL- Carya glabra; COFL-

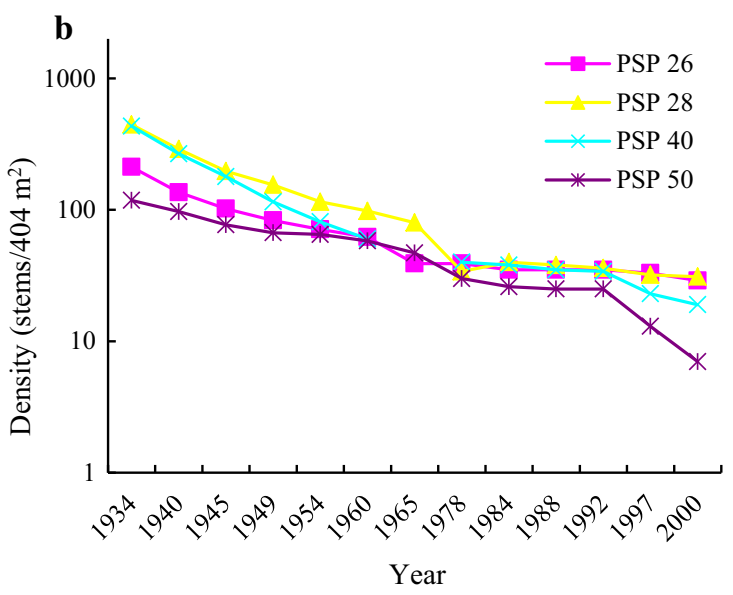

mortality has led to convergence in density during the 66-year period. Four of the permanent plots (PSP 14, 19, 49 and 50) were severely damaged by 1996 Hurricane Fran, and resulted in substantially high mortality and low tree density

50-year period following the storm, allows for the evaluation of the impact on forest development and possible long-term effects. In general, Hurricane Hazel had a smaller long-term effect on loblolly pine stands than on uneven-aged hardwoods.

To detect whether hurricane damage had long-term effects on tree species composition, we compared diversity changes in a pair of pine PSPs, one modestly damaged by Hurricane Hazel (PSP 40, lost 14\% basal area during Hazel), and the other with minimal damage (PSP 28, lost $3.5 \%$ basal area during Hazel). The two PSPs were both $808 \mathrm{~m}^{2}$ in size and 15-year-old in 1933 . There was only a weak increase in diversity on the damaged plot. Although the species number in PSP 40 is not always significantly

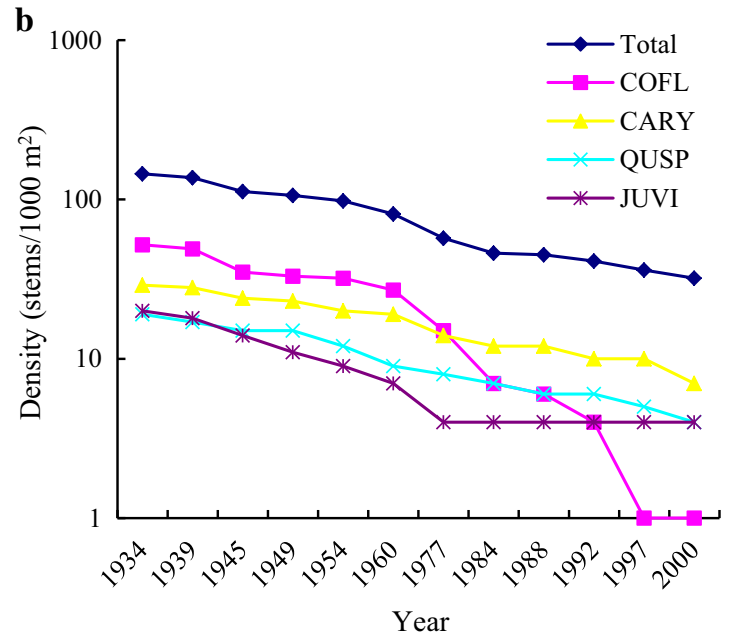

Cornus florida; JUVI- Juniperus virginiana; QUSP-Quercus spp. Quercus spp. in PSP 10 and Cornus florida in PSP 36 greatly decreased shortly after Hurricane Fran 
higher, the species diversity index $\left(H^{\prime}\right)$ is weakly higher than in the control plot, possibly owing to reduced dominance by loblolly pine.

One damaged young pine stand (PSP 20) lost $9 \%$ of previous basal area during Hurricane Hazel plus an additional $9 \%$ basal area removed in a thinning treatment immediately after Hazel, while its paired control plot (PSP 21) was subject to no damage in the 1954 Hurricane Hazel and received no thinning treatment before or after Hazel. These plots had reached similar diversity values in 1992, about 50 years after Hazel. Similarly, a comparison of PSP 39 , a pine stand which lost $36.3 \%$ previous basal area with PSP 28, a pine control which lost only $3.5 \%$ basal area during Hazel, showed that the species diversity is slightly higher (but mixed in terms of species richness) in the damaged PSP than in the control. These results suggest that thinning treatments after hurricane damage has relatively little effect on species composition and diversity, particularly when the hurricane impact comes in the thinning phase of the succession process.

In contrast with the few long-term effects of hurricanes on the thinning-phase loblolly pine stands, we found clear evidence of positive effects on hardwood stands. Tree species diversity in a severely damaged oak stand (PSP 37) increased significantly over a 50 -year period following the storm. This severely damaged plot lost $42 \%$ of the previous basal area during Hazel, whereas the control oak plot (PSP 36 ) had only minor damage (6\% previous basal area loss). Species diversity in the severely damaged plot decreased immediately after Hazel, remained low another 5 years, and then dramatically increased by a factor of four in the late 1980s, but decreased slightly in the 1990s. In 2000, the level of tree diversity was still about twice that of the control plot (Fig. 3). The diversity changes in the two oak hardwood plots, with identical community attributes preHazel, suggests that hurricane damage severity was the major control factor for this species diversity increase. This

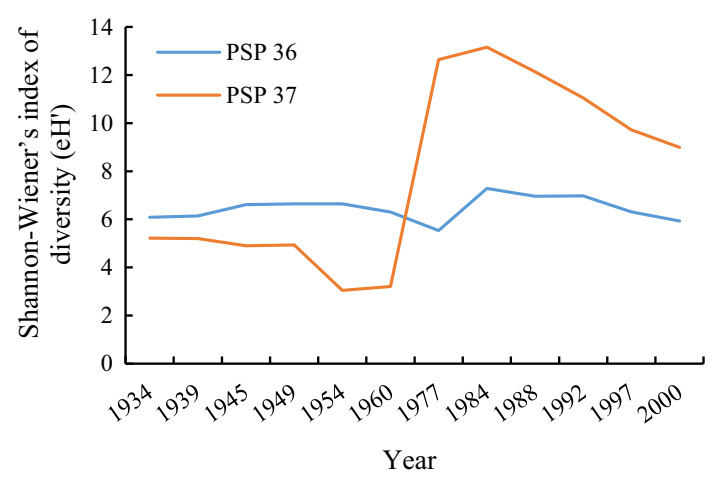

Fig. 3 Effect of 1954 Hurricane Hazel on tree diversity in an upland hardwood forest (PSP 36) and an upland hardwood forest (PSP 37) over 46 years in the Duke Forest suggests that a loss of about $40 \%$ basal area may be over a threshold value for significantly affecting long-term species composition and diversity.

In summary, the effects of 1954 Hurricane Hazel on species diversity are stronger in later successional hardwood stands than on early successional pine stands. As we will show below, the effects of the hurricane were reversed during 1996 Hurricane Fran to largely impact the transition-phase pine stands in the Duke Forest.

\section{Effects of 1996 Hurricane Fran on canopy and understory tree species diversity}

In September 1996, 42 years after Hazel, Duke Forest experienced another powerful hurricane damage event, Hurricane Fran. Two large mapped plots representing a transition-phase pine stand (MAP 1) and a mature hardwood stand (MAP 2) demonstrate the relatively short-term hurricane effects on tree diversity and forest successional trajectory.

Following Fran, species richness and diversity of small trees increased somewhat in both the loblolly pine and the mixed hardwood stands (Fig. 3). In addition, the total number of species present in the mapped pine plots increased slightly for tree species $(\mathrm{DBH} \geq 1 \mathrm{~cm}) 5$ years after the hurricane. In the two mapped pine stands, three light-demanding, fast-growth tree species, and two woody shrubs species were recruited into the stands after the hurricane.

The importance of the dominant species in both pine and hardwood forests decreased substantially due to the high mortality of canopy trees (Xi et al. 2008a, b), but the overall ranking of dominant tree species did not change. The damage severity (loss of basal area) varied slightly between the two MAPs. In the two large mapped pine forest plots, pine decreased in importance value, (a combination of relative density and relative basal area), from a pre-hurricane level of $34.5 \%$ in 1992 to $32.0 \%$ in 1997, and continued to decline to $28.3 \%$ in 2000 . The dominant $Q$. alba (white oak) decreased in importance value from $38.1 \%$ (1993) to $36.2 \%$ (1997) and continued to decline to $34 \%$ (2000) (Table 3). The 80-year loblolly pine stand lost about 20\% of its basal area between 1993 and 1997, and the oak about $16 \%$.

Understory tree (stems between 1 and $5 \mathrm{~cm} \mathrm{DBH}$ ) richness exhibited a minor decrease immediately after Hurricane Fran in 1997 in both pine stands and hardwood forest plots, followed by a rebound of richness and a gradual recovery and enhancement in species richness to the level that slightly exceeded richness levels prior to the hurricane 5 years after Fran (Fig. 4). Similar patterns can be seen for species diversity without an immediate drop after Fran. There were no tree species lost through 
Table 3 Change in relative abundance by shade-tolerance class in a 1.3 ha mapped loblolly pine stand (MAP 1) and a 1.9 ha oak forest (MAP 2) in the Duke Forest after Hurricane Fran

\begin{tabular}{|c|c|c|c|c|c|}
\hline \multirow[t]{3}{*}{ Tolerant class* } & \multirow[t]{3}{*}{ Species } & \multicolumn{4}{|c|}{ Percentage of IV } \\
\hline & & \multicolumn{2}{|c|}{ Pine stand } & \multicolumn{2}{|c|}{ Oak stand } \\
\hline & & 1992 & 2001 & 1993 & 2000 \\
\hline \multirow[t]{4}{*}{ Very tolerant (able to survive in very deep shade) } & Acer barbatum & 0.16 & 0.57 & - & 0.02 \\
\hline & Carpinus caroliniana & 2.55 & 2.67 & - & 0.01 \\
\hline & Fagus grandifolia & 0.21 & 1.03 & - & 0.02 \\
\hline & Ostrya virginiana & 2.28 & 6.29 & - & 0.01 \\
\hline \multirow[t]{6}{*}{ Tolerant (able to survive in deep shade) } & Acer rubrum & 14.98 & 15.63 & 24.19 & 29.97 \\
\hline & Cercis canadensis & 0.26 & 0.20 & - & - \\
\hline & Cornus florida & 9.36 & 6.27 & 11.07 & 7.17 \\
\hline & Fraxinus americana & 0.26 & 0.34 & 0.18 & 0.25 \\
\hline & Oxydendrum arboreum & 3.26 & 3.70 & 9.19 & 9.75 \\
\hline & Ulmus rubra & 0.71 & 0.79 & 0.01 & 0.01 \\
\hline \multirow[t]{9}{*}{ Intermediate (able to survive in modest shade) } & Carya alba & 7.71 & 7.64 & 1.51 & 1.68 \\
\hline & Carya glabra & 1.05 & 1.03 & 1.46 & 1.76 \\
\hline & Carya ovata & 0.23 & 0.19 & 0.89 & 0.94 \\
\hline & Juniperus virginiana & 0.59 & 0.45 & 0.61 & 0.66 \\
\hline & Nyssa sylvatica & 0.53 & 0.44 & 3.01 & 3.00 \\
\hline & Quercus alba & 1.45 & 1.72 & 38.10 & 34.01 \\
\hline & Quercus velutina & 1.40 & 0.65 & 1.97 & 1.36 \\
\hline & Ulmus alata & 0.43 & 0.53 & 0.04 & 0.04 \\
\hline & Ulmus americana & 0.15 & 0.03 & - & - \\
\hline \multirow[t]{5}{*}{ Intolerant (generally unable to survive very long in deep shade) } & Liquidambar styraciflua & 10.59 & 12.31 & 0.01 & 0.06 \\
\hline & Liriodendron tulipifera & 5.63 & 7.38 & 0.33 & 1.07 \\
\hline & Prunus serotina & 0.11 & 0.18 & 0.74 & 1.74 \\
\hline & Quercus falcata var. falcata & 0.10 & 0.06 & 0.25 & 0.35 \\
\hline & Quercus stellata & - & - & 0.95 & 0.79 \\
\hline Very intolerant (unable to survive very long in very deep shade) & Pinus taeda & 34.52 & 28.25 & 0.50 & 0.60 \\
\hline
\end{tabular}

*This shade tolerance classification was compiled mainly based on Burns and Honkala (1990) adjustment of the shade tolerance class has been made for some species based on our observations in Piedmont forests

Hurricane Fran, and 5 years after the hurricane a modest increase in number of exotic species and shrubs was evident in both pine stands and in uneven-aged upland hardwood stands. Some existing understory hardwood species, including Acer rubrum (red maple), Liriodendron tulipifera (tuliptree) and Liquidambar styraciflua (sweetgum), increased in their importance in both the pine and hardwood stands. Major new species in MAPs were Ailianthus altissima (Mill.) Swingle (tree-of-heaven), Asimina triloba (L.) Dunal (pawpaw), Celtis laevigata Willdenow (sugarberry), and some deciduous shrub species (Ligustrum, Rhododendron, and Viburnum).

\section{Change in abundance of shade-tolerant understory species after 1996 Hurricane Fran}

Hurricane Fran altered the abundance of shade-tolerant understory species. We grouped and compared very tolerant, tolerant, intermediate, intolerant, and very intolerant species before and after Fran among samplings and different size classes of trees (Table 3).

Our results show that the hurricane significantly increased the dominance of pre-established, more shadetolerant species, owing to advanced regeneration. Hurricane Fran greatly decreased pine dominance, and substantially increased hardwood dominance in transitionphase loblolly pine stands. This wind event resulted in a significant increase in dominance of Acer rubrum (red maple) in the oak forest. Some shade-intolerant species, 

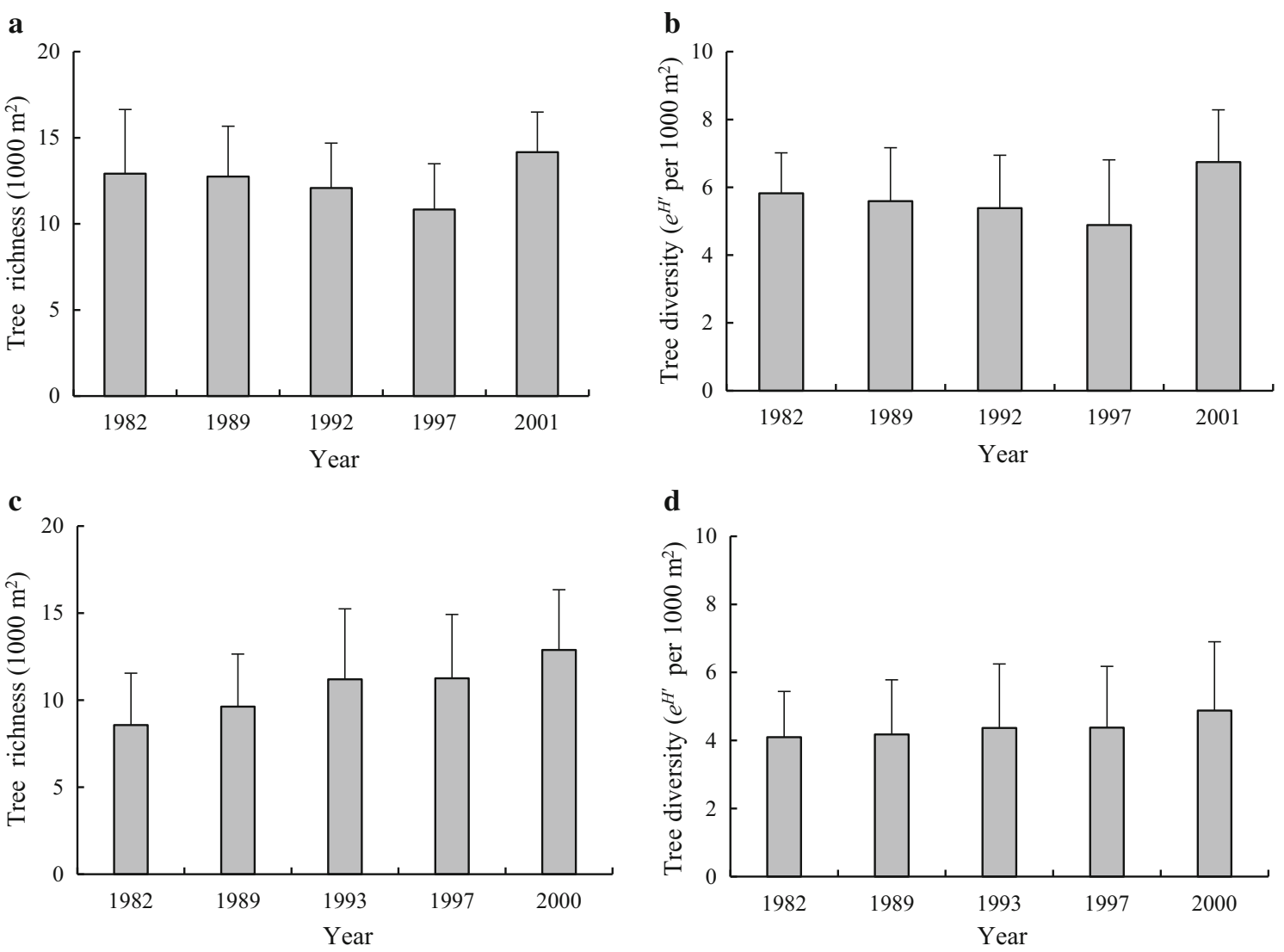

Fig. 4 Change in understory (stems DBH $\leq 1 \mathrm{~cm}$ ) species richness (number of species per ca. $\left.1000 \mathrm{~m}^{2}\right)$ and tree diversity $\left(e^{H^{\prime}}\right.$ per ca. $\left.1000 \mathrm{~m}^{2}\right)$ in two mapped permanent plots. a Tree richness in MAP 1;

such as Liquidambar styraciflua (sweetgum), Liriodendron tulipifera (tuliptree), and Ostrya virginiana (Mill.) K. Koch (American hornbeam), increased in the stands after Hurricane Fran, but their ability to influence stand tree diversity is still limited after only 5 years of hurricane recovery.

\section{The effects of hurricanes on forest succession trajectory}

The hurricane disturbances had different effects on the dynamics of the loblolly pine stands and the hardwood stands. In the pine stands, the rate of forest succession towards a more mixed pine and hardwood forest increased due to the selective damage on the large canopy pines which accelerated successional thinning and increased growth of light-demanding, understory hardwood trees (Xi et al. 2008a, b). In the hardwood stands, successional status became a diverse mosaic. Deciduous mixed-aged hardwood forests have been described as the mature, steadystate, or natural late successional forest in Piedmont forests, but in their different stages of maturation, the hardwoods experience somewhat different succession or recovery from disturbances (Christensen and Peet 1984).

b Tree diversity in MAP 1; c Tree richness in MAP 2; and $\mathbf{d}$ tree diversity in MAP 2. The bars are standard errors

Recovery of hardwood forests in the study area following disturbance is complex since the stands are mixed with varied size tree gaps, and both early and late successional species due to the selective damage on canopy trees and increased growth of understory hardwood species like red maple.

Ordination of selected control PSPs from 1933 to 2000 (Fig. 5) and seven MAPs from 1978 to 2000 (Fig. 6) summarize overall changes in species composition. As shown in Fig. 5, the thirteen PSP controls show significant separation by forest types (pine vs. hardwood stands). There is strong evidence of consistency in directions of change across all composition plots based on the orientation of the NMS succession vectors prior to 1997 Hurricane Fran. Three severely damaged PSP controls, (PSPs 14, 19 and 50), shifted the directions of their succession vectors. This implies that there was a consistent trend among plots in species composition change between 1933 and 1992-1993 prior to Hurricane Fran. Hurricane-damaged PSP plots showed a similar direction and extent of compositional change to the non-hurricane-damaged controls.

The rate of succession was significantly increased for damaged pine and hardwood stands. NMS ordination 


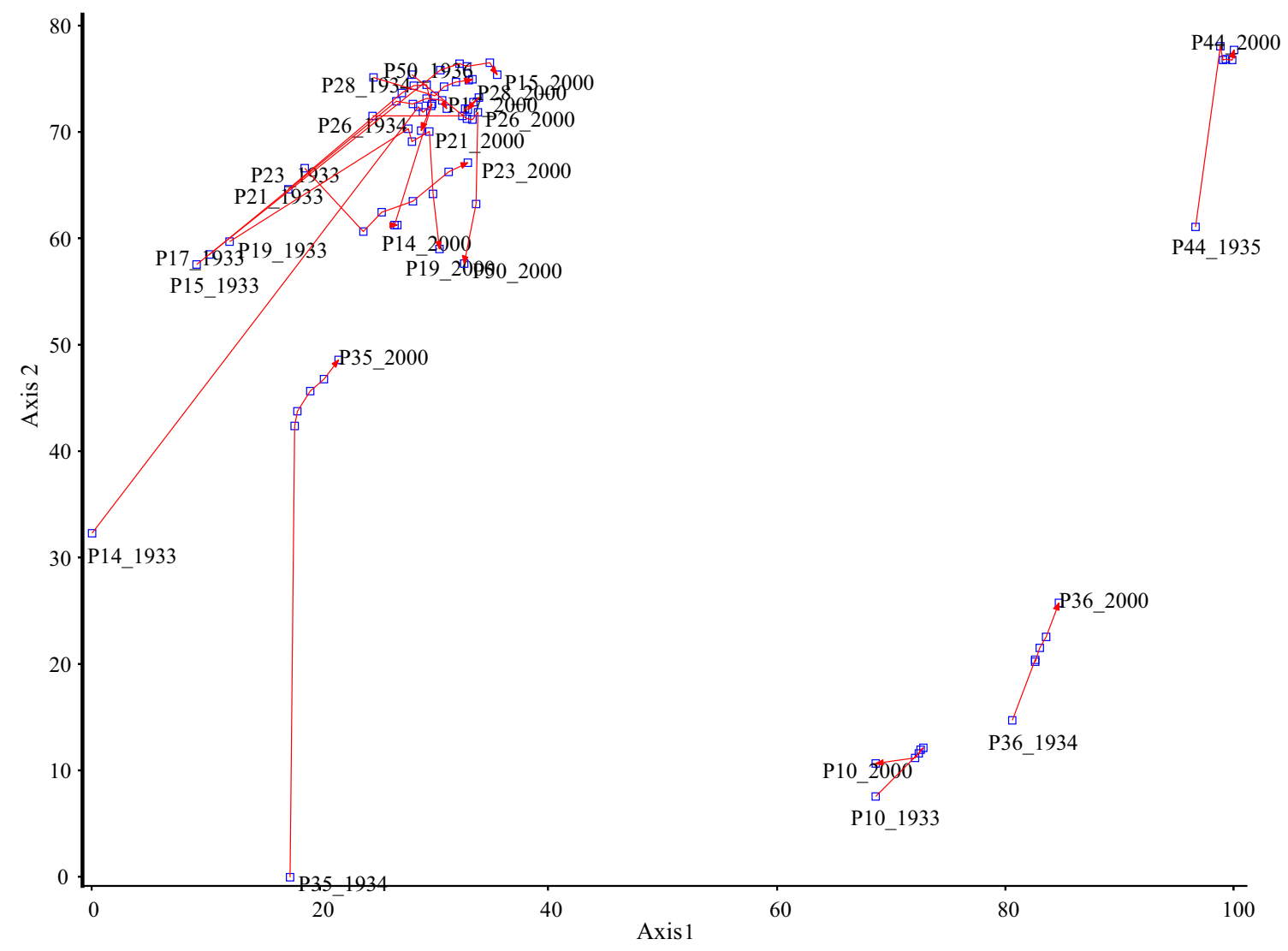

Fig. 5 Nonmetric Multidimensional Scaling ordination of 14 control permanent sampling plots. Vectors indicate sequences of observations of a single plot over the interval 1933-2000

clearly separates the seven mapped plots (see Fig. 6). The two pine mapped plots were on the right side of the ordination, (the first axis of the ordination space), and moved toward the upper side of the space. They appeared to shift in a similar direction and larger extent of compositional change after Hurricane Fran (Fig. 6). The damaged pine stands appeared to move at faster rates in the species space, whereas the hardwood stands were more stable after the hurricane damage.

\section{Discussion}

\section{Tree diversity dynamics during old-field succession}

Changes in species diversity in the 20 selected pine PSPs over a nearly 70-year period are consistent with the fourstage succession model proposed by Peet and Christensen (1988). The model predicts species diversity to increase during the initial establishment phase, decline during the highly competitive thinning phase, and increase again during the transition phase. During the late successional phase, species should either decline due to the loss of the noncompetitive successional species, or if isolated from source populations, reach a peak as new climax-specialist species slowly invade (Peet and Christensen 1980, 1987; Peet 1992; Xi and Peet 2008a, b). Our results suggest that pine forests in the transition phase, (50-year old pines), generally remained stable or slightly increased in the number of tree species.

\section{Short-term effects of hurricanes on tree mortality and species diversity}

The immediate effect of a large hurricane at the stand-level is to those trees most susceptible to wind damage. Consequently, immediately following a hurricane, tree mortality is high and drives changes in composition and diversity. There is often an immediate drop in species number at a stand scale (ca. $1000 \mathrm{~m}^{2}$ ), following hurricane damage due to tree death. As there was insufficient time for significant recruitment of new species, this change is a possible consequence of increased evenness resulting from disproportionate loss of the most abundant canopy species. The degree of direct effect is controlled by both the actual stand damage level and pre-community attributes. A combination of intensity of windstorms and pre-hurricane community attributes may play a major role in determining tree 
Fig. 6 Nonmetric

Multidimensional Scaling ordination of seven mapped plots measured from 1978 through to 2000. Squares are plot locations in twodimensional NMS ordination space over time. Observations are labelled with specific plot and year. Abbreviation M1 refers MAP 1, M2 refers MAP 2, M3 refers MAP 3, M4 refers MAP 4, M5 refers MAP 5, M6 refers MAP 6, and M7 refers MAP 7. Hardwood plots (M2, M4, M5, M6 and M7) are on the left and bottom, successional pine plots (M1 and M3) are in the upper right

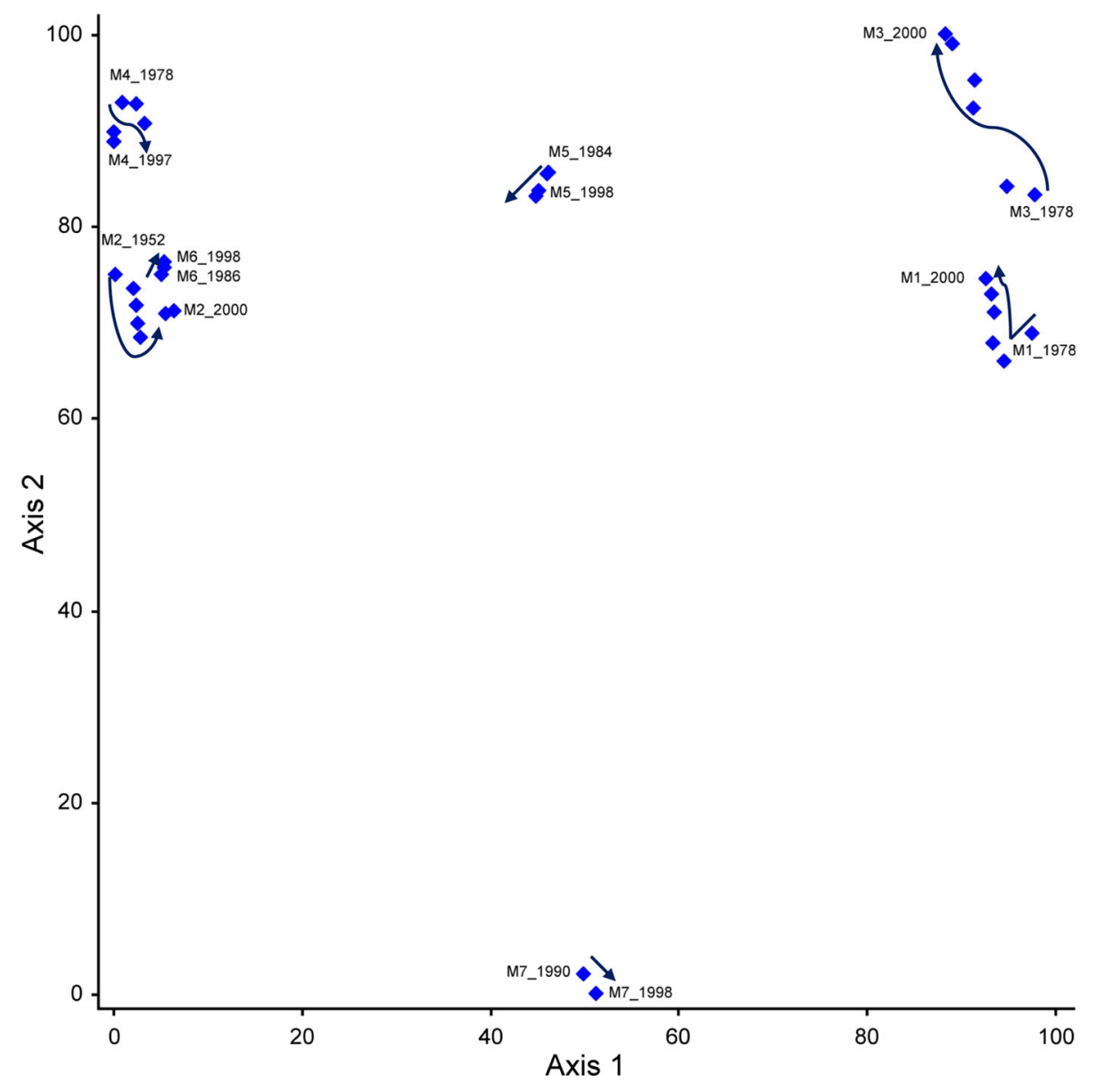

diversity dynamics (Xi 2005; Xi et al. 2008a, b; Xi and Peet 2008a, b; Xi 2015).

The major biological effect of hurricane damage, as demonstrated in this study, is to promote and synchronize regeneration and advanced growth. Species diversity of saplings quickly increases to levels typically exceeding those prior to the disturbance (Xi et al. 2011). This typically leads to a gradual increase in diversity (sometimes by as much as a factor of two), in substantially damaged stands. This pattern has parallels in reports from other regions (Webb 1999).

Previous work on tree population dynamics (Peet and Christensen 1980) and species diversity (Peet and Christensen 1988) during secondary succession in North Carolina Piedmont forests showed that species diversity is a dynamic process and that wind throws may be necessary for the persistence of many species such as Liquidambar styraciflua (sweetgum) and Liriodendron tulipifera (tuliptree). Our findings support this hypothesis, but the response was much more rapid than expected, being clearly evident only five years after the hurricanes.

\section{Long-term effects of hurricanes on tree diversity in the Piedmont forests}

Many have hypothesized that hurricanes have a long-lasting effect on younger mixed-deciduous hardwood stands by allowing new species to invade owing to reduced competition, and by affecting the balance of understory regeneration (e.g., Merrens and Peart 1992; Webb 1999; Peterson 2000; Xi and Peet 2011; Muscolo et al. 2014). However, as numerous studies on hurricane damage have pointed out, changes in diversity need to be examined over a long-term period following disturbance. In this study, nearly 70 years of data show that large, infrequent wind disturbances can increase stand level tree diversity, and in particular, that a basal area loss of over $40 \%$ can lead to a significant increase in diversity over a 50-year period. Although tree gaps caused by more frequent, low intensity windstorms are too small to maintain species diversity (Beckage et al. 2000), strong hurricanes, such as the 1938 hurricane in New England (70-80\% basal area, loss), can decrease species diversity and initiate secondary succession (Foster and Boose 1992). 


\section{The influences of historical hurricane disturbances on forest compositional trajectory}

From a broad perspective, large-scale farming in the $1800 \mathrm{~s}$ and subsequent farmland abandonment from the middle 1800 s to the early 1900 s largely initiated secondary forest succession in the Piedmont region (Oosting 1942; Peet and Christensen 1980). Had large hurricanes not occurred, time and small natural disturbances (e.g., treefall gaps, ice storms), would have slowly removed the over mature pines and therefore have gradually led to replacement by hardwoods in a predictable manner (Peet and Christensen 1988).

The role of hurricanes on forest succession is complex and depends on the combination of several biotic and abiotic factors (Xi and Peet 2011; Xi 2015). Hurricanes Fran and Hazel had varied effects but generally hastened the rate of pine replacement by hardwoods and therefore accelerated the succession process in even-aged loblolly pine stands. Hurricane Hazel impacted a thinning phase pine stand by removing pine trees, but had little effect on overall tree composition and diversity; Hurricane Fran also increased pine mortality but also accelerated the dominance of red maple in the somewhat older pine stands owing to the greater advanced regeneration in the understory.

In the Piedmont forest region, high intensity hurricane impacts are rare relative to tree longevity. Wind intensity and frequency appear to be the two key factors that determine the extent of wind effects on forest dynamics and diversity in the Piedmont. The return interval of large wind events in the Duke Forest is about 50 years, but the impact of such events is patchy, such that only a modest portion of the forest may be strongly impacted by such an event (Xi et al. 2008a).

Alteration of succession in pine forests by large-scale hurricanes has been reported elsewhere for temperate forests. For example, the 1938 hurricane in New England heavily damaged Pinus strobus L., advancing successional turnover to hardwoods that were, in some cases, already present in the understory (Spurr 1956; Hibbs 1983; Foster and Boose 1992). Hibbs (1983) reported that the 1938 hurricane which caused, in some cases over $30 \%$ mortality (70-80\% basal area loss), had long-lasting effects on many aspects of these New England forests, including succession. Palmer et al. (2000) reported the same pattern in Minnesota forests. This pattern may be particularly common in temperate old-field forests because of the high canopy stature and typically weaker wood associated with fast-growing successional species. More moderate wind disturbance tends to have little long-term effect on forest structure, growth rates, or other ecosystem properties. This study of the relationship between hurricane damage and forest dynamics, like others (Putz and Sharitz 1991), suggests that catastrophic windthrow can accelerate succession in temperate pine forests by removing the canopy of pioneer tree species to a transition to a mixed or hardwood dominant forest (Arevalo et al. 2000).

\section{Conclusion}

Duke Forest has experienced considerable historical variations in disturbance agents with wind being the most common after 1900. Successional change in composition and diversity, while showing some consistent patterns discernable in long-term data, is made extremely complex by the continuous overlay of disturbance events. Our work demonstrates the importance of combined long-term detailed tree demographic data and historical disturbance records for understanding forest dynamics. Although the patterns observed in the Duke Forest and reported elsewhere still need further testing to assess their generality, they have the potential to be applied widely in the temperate forests of the eastern United States.

Acknowledgements We thank the staff of the Duke Forest for logistical support. We also thank the many dedicated field assistants who participated in the project for their invaluable help with fieldwork.

Open Access This article is distributed under the terms of the Creative Commons Attribution 4.0 International License (http://crea tivecommons.org/licenses/by/4.0/), which permits unrestricted use, distribution, and reproduction in any medium, provided you give appropriate credit to the original author(s) and the source, provide a link to the Creative Commons license, and indicate if changes were made.

\section{References}

Abrams MD (1992) Fire and the development of oak forests. BioSci 42(5):346-353

Arevalo JR, DeCoster JK, McAlister SD, Palmer MW (2000) Changes in two Minnesota forests during 14 years following catastrophic windthrow. J Veg Sci 11(6):833-840

Barnes J (2001) North Carolina's hurricane history. The University of North Carolina Press, Chapel Hill, p 344

Beckage BJ, Clark S, Clinton BD, Haines BL (2000) A long-term study of tree seedling recruitment in southern Appalachian forests: the effects of canopy gaps and shrub understories. Can J For Res 30(10):1617-1631

Bormann FH (1953) Factors determining the role of loblolly pine and sweetgum in early old-field succession in the Piedmont of North Carolina. Ecol Monogr 23(4):339-358

Burns RM, Honkala BH (1990) Silvics of North America: Volume 2. Hardwoods. United States Department of Agriculture (USDA), Forest Service, Agriculture Handbook 654

Christensen NL (1977) Changes in structure, pattern and diversity associated with climax forest maturation in Piedmont, North Carolina. Am Midl Nat 97(1):176-188 
Christensen NL, Peet RK (1981) Secondary forest succession on the North Carolina piedmont. In: West DC, Shugart HH, Botkin DB (eds) Forest succession: concepts and application. Springer, New York, pp 230-245

Christensen NL, Peet RK (1984) Convergence during secondary forest succession. J Ecol 72(1):25-36

Elliott KJ, Hitchcock SL, Krueger L (2002) Vegetation response to large scale disturbance in a southern Appalachian forest: hurricane opal and salvage logging. $J$ Torrey Bot Soc 129(1):48-59

Everham EM, Brokaw NVL (1996) Forest damage and recovery from catastrophic wind. Bot Rev 62(2):113-185

Foster DR, Boose ER (1992) Patterns of forest damage resulting from catastrophic wind in central New England, USA. J Ecol 80(1):79-98

Glitzenstein JS, Harcombe PA, Streng DR (1986) Disturbance, succession, and maintenance of species-diversity in an east Texas forest. Ecol Monogra 56(3):243-258

Greenberg CH, McNab WH (1998) Forest disturbance in hurricanerelated downbursts in the Appalachian mountains of North Carolina. For Ecol and Manage 104(1):179-191

Hibbs DE (1983) 40 years of forest succession in central New England. Ecology 64(6):1394-1401

Imbert D, Rousteau A, Labbe P (1998) Hurricanes and biological diversity in tropical forests - the case of Guadeloupe. Acta Oecol 19(2):251-262

Jenkins M, White PS (2002) Cornus florida L. mortality and understory composition changes in western Great Smoky Mountains National Park. J Torrey Bot Soc 129(3):194-206

Li XF, Jin L, Zhu JJ, Liu LM, Zhang JX, Wang Y, Zhu CY (2018) Response of species and stand types to snow/wind damage in a temperate secondary forest, Northeast China. J For Res 29(2):395-404

McCune B, Grace JB (2002) Analysis of ecological communities. Oregon, MjM Software Design, Gleneden Beach, p 300

McDonald RI, Peet RK, Urban DL (2002) Environmental correlates of oak decline and red maple increase in the North Carolina Piedmont. Castanea 67(1):84-95

Merrens EJ, Peart DR (1992) Effects of hurricane damage on individual growth and stand structure in a hardwood forest in New Hampshire, USA. J Ecol 80(4):787-795

Muscolo A, Bagnato S, Sidari M, Mercurio R (2014) A review of the roles of forest canopy gaps. J For Res 25(4):725-736

Oosting HJ (1942) An ecological analysis of the plant communities of piedmont, North Carolina. Am Midl Nat 28(1):1-126

Owari T, Kamata N, Tange T, Kaji M, Shimomura A (2011) Effects of silviculture treatments in a hurricane-damaged forest on carbon storage and emissions in central Hokkaido, Japan. J For Res 22(1):13-20

Palmer MW, Mcalister SD, Arevalo JR, DeCoster JK (2000) Changes in the understory during 14 years following catastrophic windthrow in two Minnesota forests. J Veg Sci 11(6):841-854

Palmer MW, Peet RK, Reed RA, Xi W, White PS (2007) A multiscale study of vascular plants in a North Carolina Piedmont forest. Ecology 88(10):2674

Peet RK (1974) The measurement of species diversity. Annu Rev Ecol Syst 5:285-307

Peet RK (1992) Community structure and ecosystem properties. In: Glenn-Lewin DC, Peet RK, Veblen TT (eds) Plant succession: theory and prediction. Chapman and Hall, London, pp 102-151
Peet RK, Christensen NL (1980) Succession-a population process. Vegetatio 43(1-2):131-140

Peet RK, Christensen NL (1987) Competition and tree death. Bioscience 37(8):586-595

Peet RK, Christensen NL (1988) Changes in species diversity during secondary forest succession on the North Carolina piedmont. In: During HJ, Werger MJA, Willems J (eds) Diversity and pattern in plant communities. SPB Publishers, The Hague, pp 233-245

Peet RK, Wentworth TR, White PS (1998) A flexible, multipurpose method for recording vegetation composition and structure. Castanea 63(3):262-274

Peterson CJ (2000) Catastrophic wind damage to North American forests and the potential impact of climate change. Sci Total Environ 262(3):287-311

Putz FE, Sharitz RR (1991) Hurricane damage to old-growth forest in Congaree Swamp National Monument, South Carolina, USA. Can J For Res 21(12):1765-1770

Spurr SH (1956) Natural restocking of forests following the 1938 hurricane in central New England. Ecology 37(3):443-445

Vandermeer J, Cerda IGDL, Boucher D, Perfecto I, Ruiz J (2000) Hurricane disturbance and tropical tree species diversity. Science 290(5492):788-791

Webb SL (1999) Wind disturbances in temperate forests. In: Walker LR (ed) Ecosystems of disturbed ground. Elsevier, Amsterdam, pp 187-222

White PS, Jentsch A (2004) Disturbance, succession, and community assembly in terrestrial plant communities. In: Temperton V, Hobbs R, Halle S (eds) Assembly rules and restoration ecology. Island Press, Washington, DC, pp 342-366

$\mathrm{Xi}$ W (2005) Forest response to natural disturbance: Changes in structure and diversity on a North Carolina piedmont forest in response to catastrophic wind events. Ph.D. dissertation, The University of North Carolina at Chapel Hill, Chapel Hill, North Carolina, USA

Xi W (2015) Synergistic effects of tropical cyclones on forest ecosystems: a global synthesis. J For Res 26(1):1-21

Xi W, Peet RK (2008a) Long-term studies of forest dynamics in the Duke Forest, southeastern United States: a synthesis. J Plant Ecol (Chinese Version) 32(2):299-318

Xi W, Peet RK (2008b) Hurricane effects on the Piedmont forests: patterns and implications. Ecol Restor 26(4):295-298

Xi W, Peet RK (2011) The complexity of catastrophic wind impacts on temperate forests. In: Anthony Lupo (ed) Recent Hurricane research-climate, dynamics and sociatal impacts. ISBN 978-953-307-238-8. IN-TECH, Vienna, Austria. pp 503-534

Xi W, Peet RK, Urban DL (2008a) Changes in forest structure, species diversity, and spatial pattern following hurricane disturbance in a Piedmont North Carolina forest, USA. J Plant Ecol 1(1):43-57

Xi W, Peet RK, DeCoster JK, Urban DL (2008b) Tree damage risk factors associated with large, infrequent wind disturbances of Carolina forests. Forestry 81(3):317-334

Xi W, Peet RK, Urban DL (2011) The impacts of large hurricane on understory sapling dynamics and diversity in North Carolina Piedmont forests, USA. Tree For Sci Biotechnol 6(1):51-59

Yang H, Liu SR, Cao KF, Wang JX, Li YD, Xu H (2017) Characteristics of typhoon disturbed gaps in an old-growth tropical montane rainforest in Hainan Island, China. J For Res 28(6):1231-1239

Zhu JJ, Liu ZG, Li XF, Matsuzaki T, Gonda Y (2004) Review: effects of wind on trees. J For Res 15(2):153-160 